Pendulum Observations in the Northern and Southern Hemispheres.

THE figure of the earth has been determined by three independent methods of investigation. (I) By abstract mathematical calculation of the form which such a body as the earth, rotating as it does, would assume when plastic. (2) By careful measurements of arcs on meridian lines in different latitudes. (3) By pendulum experiments, which have indicated a gradual increase of the force of gravity from the equator towards the poles.

These three methods, after necessary corrections have been applied, correspond so nearly in their results that probably we have ascertained the true ellipticity of our earth as nearly as is possible considering the irregularities of its surface. But there is one point in connection with pendulum experiments which, although it cannot have escaped notice, has not been treated of as far as I am aware, in any work on astronomy or geodesy, viz. that all the pendulum experiments hitherto made in the southern hemisphere indicate that the force of the earth's attraction is less in that hemisphere than in the northern. The great navigator, Captain Cook, was the first, I believe, to notice this phenomenon in connection with an excellent pendulum clock which he carried with him. He noticed that this clock always went slower at places in the southern hemisphere than it did in the northern hemisphere; but he did not pursue the question.

In November I893, Dr. John Murray read a paper on Antarctic research before the Royal Geographical Society, and in the appendix to that paper is a communication from Dr. Neumayer, of the Hamburgh Naval Observatory, giving a table of the results of pendulum experiments hitherto made in the southern hemisphere. In the annexed table I have made use of Dr. Neumayer's collected information, reducing his values of the length of pendulum beating seconds, given in metres, to the corresponding values of the accelerating force of gravity in foot seconds, and I have added, from other sources available to me here, the corresponding values of $g$ at places in nearly similar north latitudes. By comparison it will be seen that the force of gravity in the northern hemisphere exceeds that in the southern hemisphere, in latitudes between $38^{\circ}$ and $62^{\circ}$, by a mean of about 'oro. In Dr. Neumayer's table, experiments in the southern hemisphere are recorded as far as lat. $33^{\circ} 2^{\prime} 5^{\prime \prime} \mathrm{S}$. (Valparaiso), but I have not been able to obtain here any records in similar latitudes in the northern hemisphere. In the northern hemisphere experiments have been made at Hammerfest $70^{\circ} 40^{\prime}$ north latitude, and at Spitzbergen $79^{\circ} 49^{\prime} 54^{\prime \prime}$ north latitude; but no corresponding experiments have yet been made in Antarctic regions.

Taking, however, the values of $g$ at Edinburgh and at Cape Horn, in very nearly the same latitudes, $55^{\circ}$ north and south, viz. $32^{\prime} 204$ and $32^{\prime} 194$, and assuming that these values will not vary greatly in their difference at the poles; by a simple calculation we find that the centre of gravity of the earth is approximately $\frac{3}{10}$ ths of a mile north of the plane of the equator. It would appear from this that in astronomical observations depending on zenith distances, and consequently on the direction of the plumh-line, not only must corrections be made for the ellipticity of the earth, but also for the true position of the centre of gravity of the earth, which at the equator must deflect the plumb-line about $15^{\prime \prime}$ from the true vertical.

It is a deeply interesting question whether astronomical observations can be, or have been, made to verify the results obtained by the pendulum.

Geographically it is a subject which may approximately be investigated by comparing the masses of dry land now standing above the sea-level in the northern and southern hemispheres; the excess of dry land in the northern hemisphere, at present, being the probable cause of shift of the centre of gravity of the earth northwards.

In mathematical astronomy it presents an extremely difficult but highly important problem, viz. what effect this position of the centre of gravity of the earth has upon the gyratory motion, producing the precession of the equinoxes, which is caused by the attractions of the sun and moon on the equatorial protuberance.

If, as seems probable, a shift in the position of the centre of gravity of the earth north or south of the plane of the equator must produce a shift also in the direction of the axis of gyration, many perplexing geological problems as to varying climates in the same part of the world during different epochs in the world's past history would be at least partially elucidated. There is ample evidence of very widely-extended earth movements of elevation and depression in the past; these must have varied the balance of the earth, and if a change in the balance produces also a change in the direction of the axis of gyration, a change in climate follows as a matter of course.

It is a problem requiring mathematical genius and skill of the highest order for its solution; but it can be hardly denied that it is of very great scientific interest that it should be correctly solved.

Finally, I would wish to draw attention to the importance of accurate pendulum experiments being made in the highest southern latitudes attainable by the Antarctic research parties which are either now being organised, or will, it is hoped, even tually be despatched by the British Government.

\begin{tabular}{|c|c|c|c|c|c|c|}
\hline Place. & N. lat. & $\begin{array}{l}\text { Value of } \\
g . \text { ft.sec. }\end{array}$ & Diff. & $\begin{array}{l}\text { Value of } \\
g \text {.ft. sec. }\end{array}$ & S. lat. & Place. \\
\hline Washington, & & & & & & \\
\hline Paris ... $\quad \ldots$ & $\begin{array}{l}38^{\circ} 54^{\prime} \\
4^{\circ} 5^{0^{\prime}}\end{array}$ & $\begin{array}{l}3^{2} \times 155^{8} \\
3^{2} \cdot 183\end{array}$ & $\begin{array}{l}.013 \\
.009\end{array}$ & $\begin{array}{l}3^{2}+142 \\
3^{2} \cdot 174\end{array}$ & $\begin{array}{l}37^{\circ} 49^{\prime} 9^{\prime \prime} \\
49^{\circ} 8^{\prime} 9^{\prime \prime}\end{array}$ & $\begin{array}{l}\text { Melbourne. } \\
\text { Kerguelen } \\
\text { Island. }\end{array}$ \\
\hline & & & oIs & $32 \cdot 182$ & $51^{\circ} 3 \mathrm{I}^{\prime} 7^{\prime \prime}$ & Falkland Is. \\
\hline & & & & $3^{2} \times 178$ & $51^{\prime \prime} 35^{\prime} 3^{\prime \prime}$ & $\begin{array}{l}\text { Falkland Is. } \\
\text { No. 2. }\end{array}$ \\
\hline Greenwich $\ldots$ & $51^{\circ} 29^{\prime}$ & $37 \cdot 19 \mathrm{r}$ & & $3^{2} \times 80$ & & $\begin{array}{l}\text { Mean of Nos. } \\
\text { I and } 2 .\end{array}$ \\
\hline $\begin{array}{ll}\text { Belfast } & \ldots \\
\text { Edinburgh } & \ldots\end{array}$ & $54^{\circ} 36^{\prime}$ & $\begin{array}{l}32^{2} \times 99 \\
3^{2} \cdot 204\end{array}$ & ${ }_{0}^{\circ} 8$ & $\begin{array}{l}3^{*} \cdot \mathrm{IgI} \\
3^{2} \cdot 1936\end{array}$ & $\begin{array}{l}54^{\circ} 3^{3} x^{\prime} \\
55^{\circ} 5 I^{\prime} 3^{\prime \prime}\end{array}$ & $\begin{array}{l}\text { S. Georgia } \\
\text { Cape Horn. }\end{array}$ \\
\hline $\begin{array}{l}\text { N. Shetlands } \\
\text { Interpolated ... } \\
\text { (at the rate of } \\
\text { (00275 per } \\
\text { degree) }\end{array}$ & $\begin{array}{l}60^{\circ} 45^{\prime} \\
62^{\circ} 45^{\prime}\end{array}$ & $\begin{array}{l}3^{2} \cdot 217 \\
3^{*} 222\end{array}$ & oro & $32 \cdot 212$ & & S. Shetlands. \\
\hline
\end{tabular}

N.B. - The difference in the values of $g$ between Washington and Melbourne, if corrected for difference in latitude, would become orr. Similarly that between Paris and Kerguelen Island would become oro. The variation in the difference at $54^{\circ} \cdot 3_{3}^{3}$ south and north latitudes may be due to some local attraction or some inaccuracy in observation.

Wellington, New Zealand,

H. S. SCHAw.

November 1 2, 1895 .

\section{The Metric System.}

IT may not be within the recollection of your readers, and very unlikely to be so in that of the British public, that so far back as $1870-7 \mathrm{I}$ the Government of India, in the Governor-General's Council, passed an Act to introduce the metric system into the British dominions in India. However, as all Acts passed by that Government and its Council require the prior sanction of the Secretary of State for India in Council, the measure failed to take its place on the Statute Book of the Empire. His Grace the Duke of Argyle was at that time at the India Office, and it is a matter for much regret that he did not see fit to approve of the measure. That the Government of India did not expect that the Act would be vetoed, is proved by the fact of its having adopted the system in the State Railway Branch of the Public Works Department, then but recently formed. Sir Guildford Molesworth, K.C.I.E., then Consulting Engineer to the Government of India for Railways, published a series of type drawings dimensioned in the metric system. The Government further adopted the metre as the gauge of the narrowgauge system then introduced for the first time by them. All the platform and other weighing machines sent out were so arranged as to weigh in kilogrammes, tons, and maunds. Had the wise policy of the late Lord Mayo been then approved of, the English commercial and scientific public would not now be clamouring for its adoption in the mother-country, as its great advantages would be patent to all.

In Ceylon the decimal system has been applied to the rupee, and I have not heard any complaints of inconvenience having arisen from such adoption.

Cannot a further agitation be started, to move the Government of England to take steps in the coming session to make a start, at least, in the matter? It might be notified that, for all Government contracts, no other system would be entertained after January I, I898. This in itself would give a huge impetus to the movement.

West Kensington, W., December 26, I895.

No. I 367 , VOL. 53] 